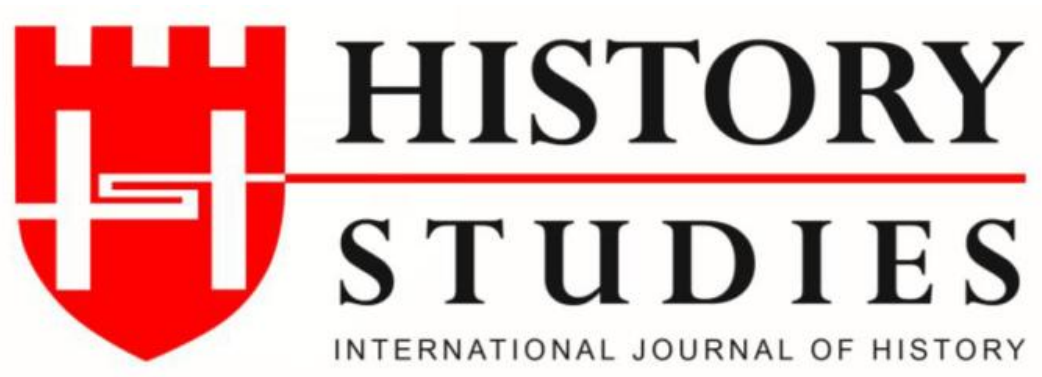

ISSN: 13094173 (Online) 1309 - 4688 (Print)

Volume 12 Issue 4, August 2020

DOI Number: 10.9737/hist.2020.912

Araştırma Makalesi

Makalenin Geliş Tarihi: 21.05.2020 Kabul Tarihi: 26.07.2020

Atıf Künyesi: Özer Özbozdağlı, "1905 İşkodra Depremi ve Afet Yönetimi”, History Studies, 12/4, Ağustos 2020, s. 2101-2115.

\title{
1905 İşkodra Depremi ve Afet Yönetimi
}

\section{Shkodra Earthquake and Disaster Management}

\author{
Dr. Özer Özbozdağlı \\ ORCID No: 0000-0003-3486-7270 \\ Hatay Mustafa Kemal Üniversitesi
}

Öz: Depremler Osmanlı coğrafyasında en sık yaşanan doğal afetlerin başında gelmektedir. Osmanlı coğrafyasının bir parçası olan İşkodra Balkan Yarımadası'nın en yüksek sismik tehlike ve risk alanlarından biridir. Tarihi kayıtlar incelendiğinde İşkodra bölgesinin şiddetli depremlere maruz kaldığı görülür. İşkodra tarihinin en yıkıcı depremlerinden biri de 1 Haziran 1905 'te meydana gelen ve büyüklüğü 6.6 olarak ölçülen depremdir. Deprem İşkodra'da ve çevresindeki köylerde ağır hasara neden oldu. Dönemin kaynakları vilayet merkezinde 1500 yapının tamamen yıkıldığını, diğer tüm binaların ağır hasar gördüğünü, şehrin harabeye döndüğünü, 200-250 kişinin hayatını kaybettiği ve 500-600 kişinin de yaralandığını belirtilmektedir. Şehirdeki evlerin $1 / 5$ 'i yıkıldığı tahmin edilmektedir. Şehrin güneybatı kısmı depremden çok ciddi bir şekilde etkilendi. Bu bölgede bulunan kenar mahallelerinde bulunan yapıların tamamı yıkıldı ve can kayıpları yaşandı. Bu mahaller bir daha eski görünümlerine kavuşamadı. Bununla birlikte İşkodra'da devlet altyapısı ağır görmüştür. Bu çalıșmada İșkodra vilayetinin gelișimini her açıdan olumsuz etkileyen 1905 depremi, sonuçları ve afet yönetimi konuları üzerinde durulacaktır.

Anahtar Kelimeler: Deprem, Osmanlı Devleti, İşkodra, Afet Yönetimi

\begin{abstract}
Earthquakes are among the most common disasters experienced in the Ottoman geography. As a part of the Ottoman geography, Shkodra is one of the highest seismic hazard and risk areas of the Balkan peninsula. When historical records are examined, it is seen that the Shkodra region was exposed to severe earthquakes. One of the most destructive earthquakes in the history of Shkodra was the earthquake that occurred on June 1,1905 , and its magnitude was measured as 6.6. The earthquake caused severe damage in Shkodra and the surrounding villages. Sources of the period indicate that 1500 buildings were completely destroyed in the province center, all other buildings were severely damaged, the city fell into ruins, 200-250 people died and 500-600 people were injured. It is estimated that $1 / 5$ of the houses in the city were destroyed. The southwestern part of the city was seriously affected by the earthquake. All of the structures in the suburbs in this region were destroyed and there was loss of lives. These suburbs could not be restored again. In addition, the state infrastructure in Shkodra was heavily damaged. This study will focus on the 1905 earthquake, which adversely affected the development of the Shkodra province in every respect, its consequences and disaster management.
\end{abstract}

Keywords: Earthquake, Ottoman Empire, Shkodra, Disaster Management 


\section{Giriş}

Deprem doğrudan doğruya kaynağını yer kabuğu veya yerin derinliklerinden alan afettir. Doğal etkenlere bağlı olarak yerkabuğunda görülen ve çoğunlukla yeryüzünde önemli değişikliklere neden olabilen kısa süreli salınım ve titreşim hareketlerine deprem denir. Ani olarak ortaya çıkan ve önlenmesi mümkün olmayan bu doğa olayı, büyük can ve mal kayıplarına neden olduğu gibi birey üzerinde ve toplumda sosyo-psikolojik yönden ciddi olumsuzluklarda yaratmaktadır. ${ }^{1}$ Deprem insana zarar veren, yaşamını derinden etkileyen, sosyal ve ekonomik kayıplara sebep olan bir doğal afettir. Bu açıdan deprem sonuçları itibarıyla tarihsel olgularında ortaya çıkmasına neden olmaktadır. Depremin insan üzerinde yarattığı etki ve travmalar, can kayıpları, göç, yerleşim yerinin yeniden şekillenmesi gibi konular depremin sonuçları olarak incelenmesi gereken tarihsel olgulardır. Bu tarihsel olgular, tarihi olayların incelenmesinde olay örgüsünün tamamlanmasına da yardımcı olur. Geçmiş örneklerin incelenmesi, yalnız birbirine sıkıca bağlı sismo-tektonik yorumlarla risk değerlendirmelerinin yapılabilmesi için değil, deprem hareketlerinin anlaşılabilmesi içinde önemlidir. ${ }^{2}$ Tarihsel incelemeler bölgedeki aktif tektonik yapıları belirlemeye yardımcı olduğu gibi, bölgenin sismik etkenlere ne kadar sıklıkla maruz kaldığının belirlenmesine de katk1 sağlar. Bu katkılar sismologlara ve yer bilimcilere öngörü için önemli veri sağlamaktadır. ${ }^{3}$ Deprem değerlendirmeleri ve analizlerini iki döneme ayırmak mümkündür; Tarihsel ve aletsel dönem. Tarihsel dönem depremleri, tarihi kayitlara ve meydana gelen hasar durumuna göre yapılan değerlendirmelerdir. 20. yüzyılın başından itibaren aletler yardımıyla depremin şiddetinin belirlendiği dönem ise aletsel dönem depremleridir.

Depremler Osmanlı coğrafyasında en sık yaşanan doğal afetlerin başında gelmektedir. Osmanlı coğrafyasının bir parçası olan İşkodra Balkan yarımadasının en yüksek sismik tehlike ve risk alanlarından biridir. İşkodra'nın sismikliği öncelikle bölgenin tektonik yapısından kaynaklanmaktadır. Tarihi kayıtlar incelendiğinde İşkodra bölgesinin şiddetli depremlere maruz kaldığı ve bu depremlerden dolayı ciddi tahribata uğradığı görülür. Kayıtlardan ve belgelerden anlaşıldığına göre, 19. yüzyılda İşkodra'da 1853, 1854, 1855, 1863 y1llarında depremler meydana geldi. ${ }^{4}$ 20. yüzyılın başlarında Avrupa'daki sismoloji istasyonlarının kurulmasıyla İşkodra ve çevresinde magnitude ${ }^{5} 6.0$ 'dan büyük depremlerin ölçülmesi mümkün oldu. ${ }^{6} 1905$-1995 döneminde magnitud 4.1'den büyük 1037 olay kaydedilmiştir. ${ }^{7}$ İşkodra tarihinin en yıkıcı depremlerinden biri de 1 Haziran 1905 'te meydana gelen ve büyüklüğü 6.6 olarak ölçülen depremdir.

1 Cemalettin Şahin- Şengün Sipahioğlu, Doğal Afetler ve Türkiye, Gündüz Eğitim ve Yayıncılık, Ankara 2007, s. 2007.

${ }^{2}$ Jean Vogt, "Osmanlı Topraklarında Tarih Boyunca Depremsellik”, Osmanlı Imparatorluğu’nda Doğal Afetler, Ed. Elizabeth Zachatadou, Tarih Vakfi Yurt Yayınları, İstanbul 2001, s. 55.

${ }^{3}$ Özer Özbozdağlı, "Osmanlı Makedonya'sında 4 Nisan 1904 Depremi ve Sonuçları”, Ankara Üniversitesi Tarih Araştırmaları Dergisi, Ankara 2020, s. 437.

${ }^{4}$ Nicolas Ambraseys, Earthquakes in the Mediterranean and Middle East: A Multidisciplinary Study of Seismicity up to 1900, London 2009, s. 655.

5 Magnitud: Belirli bir zaman diliminde kaydedilen sismogram üzerindeki deprem dalgalarının genliğinin logaritması olarak tanımlanır. Deprem odağından açı̆̆a çıkan toplam enerji, depremin büyüklüğ̈nü belirleyen en önemli unsurdur. Elde edilen bu verilerle depremin büyüklüğü detaylı olarak bulunabilir. Daha geniş Bilgi için bkz. Şahin- Sipahioğlu, age, s. 29.

${ }^{6}$ Siasi Koçiaj- E. Sulstarova ve diğerleri, Seismicity, Seismotectonics and Seismic Hazard Assessment in Albania, Academy Of Sciences of Albanina, Tiran 2010, p. 6

${ }^{7}$ Siasi Koçiaj, "Recent seismic activity in Albania and its Features", Mud Volcanoes, Geodynamics and Seismicty, Netherland 2005, p. 123. 
1905 depremi İşkodra'da meydana gelen en güçlü sismik olaylardan biridir. Bu çalışmada İşkodra'da meydana gelen deprem ve sonuçları üzerinde durulacaktır. Çalışmanın ana malzemesini arşiv belgeleri oluşturmaktadır. Depremin meydana getirdiği hasar ve zayiat gibi konular gazetelere yansımadığ 1 için arşiv malzemesi depremin yarattı̆̆ sonuçların ortaya konulması için önemli veri sağladı. Osmanlı'da deprem verilerini analiz edecek uzmanlar olmadığı için raporlarda depremin yeri (merkez üssü), çap1, etki alanı gibi veriler yoktur. Bu durum Osmanlı belgelerinin sınırlarını da çizmektedir. Bununla birlikte bölgenin tektonik koşulları, depremin doğa üzerindeki etkileri, yerleşim yerinin özellikleri, binaların durumu, yapı malzemesi, kırsal bölgelerdeki yapıların özellikleri, onarım ve güçlendirme çalışmalarının nasıl yapıldığ 1 , bölgede risk analizlerinin yapılıp yapılmadığ ile ilgili bilgiler Osmanlı belgelerine sınırlı ya da hiç yansımaması belgelerle yapılacak bir deprem çalışmasının en önemli zorluklarını oluşturmaktadır.

İşkodra, Karadağ sınırında yer alan, bir cephesi Adriyatik denizine bakan, yüksek sıradağların komşu bölgelerden ayırdığı ve Avrupa ile sınır hattında yer alan stratejik bir bölgeydi. Stratejik konumundan dolayı vali hem mülki amir hem de komutand1 ${ }^{8}$. Araştırmalara göre İşkodra vilayetinin toplam nüfusu 20. yüzyılında başlarında 250 bin civarında olduğu tahmin edilmektedir. ${ }^{9}$ Tanzimat döneminde şehir, bütün Kuzey Arnavutluk'u kapsayan bir vilayet oldu. İşkodra 19. yy. da ve 20. yüzyılın başlarında Arnavutların en önemli ticaret kentiydi. ${ }^{10}$ İşkodra, bugün Kuzeybatı Arnavutluk'ta bulunmaktadır. Depremin meydana geldiği 1905 yılında İşkodra vilayetinin idari taksimatı şu şekildeydi: ${ }^{11}$ İşkodra merkez sancağ 1 (78 kura, 5 nahiye, Leş, Tuz, Merdita ve Puka kazaları ), Draç sancağı (Tiran, Kavaye, Şiyak, Akçahisar kazları).

\section{Depremin Oluş Zamanı ve Etki Alanı}

Volume 12

1905 depremi, İşkodra vadisinin en büyük deprem serilerinden birini temsil eder. Araştırmalar 1 Haziran 1905 depreminin saat 4.42'de meydana geldiğini ve 43 saniye sürdüğünü belirtilmektedir. ${ }^{12}$ Makrosismik araştırmalar depremin merkez üssünün ${ }^{13}$ Trush köyü yakınlarında olduğunu göstermiştir. Depremin merkez üssü, İ̧sodra'nın güneybatısını, Berdice, Bahçelik (Bahçallek), Alaybey (Allajbeg) gibi kale çevresindeki eski mahalleleri ve Trush, Beltoja (Beltoje), Oblik (Oblika), Buşat (Bushat), Kozmaç (Kosmac) ve Kuç (Kuc) gibi köyleri kapsar. ${ }^{14}$ Depremin merkez üssünün vilayet merkezine yakın oluşu yıkımın fazla olmasına sebep olmuştur. İşkodra Valisi Haydar Bey İstanbul'a gönderdiği ilk bilgide "gayet dehşetli ve sürekli bir hareket-i arz" meydana geldiğini bildirmekteydi. Bundan sonra İşkodra

\footnotetext{
${ }^{8}$ Nathalie Clayer, Arnavut Milliyetçiliğinin Kökenleri, Çev. Ali Berktay, Bilgi Üniversitesi Yayınları, İstanbul 2013, s. 46.

${ }^{9}$ İlkay Erken, İşkodra Vilayetinin İdari ve Sosyal Yapısı 1876-1912, Ondokuz Mayıs Üniversitesi Sosyal Bilimler Enstitüsü, Yayınlanmamış Yüksek Lisans Tezi, Samsun 2014, s. 102.

${ }^{10}$ Machiel Kiel, "İş̧odra", Türkiye Diyanet Vakfi İslam Ansiklopedisi, C. 23, Türkiye Diyanet Vakfi Yayınları, İstanbul 2001, s. 433.

11 Salname-i Devlet-i Aliyye-i Osmaniyye, 1323 (1905) Sene-i Hicriyesine Mahsus, Matbaa-i Ahmed İhsan, Dersaadet 1321, s. 886-891.

${ }^{12}$ Koçiaj- Sulstarova ve diğerleri, age, s. 7.

${ }^{13}$ Dış Merkez (Episantr veya Merkez Üssü): Odak noktasına en yakın olan yer üzerindeki noktadır. Burası aynı zamanda depremin en çok hasar yaptığı veya en kuvvetli olarak hissedildiği noktadır. Aslında bu, bir noktadan çok bir alandır. Depremin dış merkez alanı depremin şiddetine bağlı olarak çeşitli büyüklüklerde olabilir. Bazen büyük bir depremin odak noktasının boyutları yüzlerce kilometreyle de belirlenebilir. Bu nedenle "Episantr Bölgesi" ya da "Episantr Alanı" olarak tanımlama yapılması gerçeğe daha yakın bir tanımlama olacaktır. https://deprem.sdu.edu.tr/tr/sismolojik-terimler/sismolojik-terimler-636s.html ( E.T. 4.4.2020)

${ }^{14}$ Siasi Koçiaj - E. Sulstarova, "The Earthquake of June 1, 1905, Shkodra, Albania, Intensity Distribution and Macroseismic Epicentre”, Tectonophysics, C. 67, S. 3-4, 1980, s. 320.
} 
valiliği İstanbul'a düzenli bilgiler aktarmıştır. İlk bilgilerde depremin saati ve tespit edilebilen hasar bilgileri yer almaktaydı. Osmanlı belgelerinde bu deprem için "gayet dehşetli ve sürekli hareket-i arz", "şiddetli hareket-i arz" artçı sarsintılar içinde daha çok "tezelzülat" tabirinin kullanıldığı görülmektedir. ${ }^{15}$ Deprem Makedonya, Macaristan'ın güneyinde, Bulgaristan ve İtalya'da hissedildi. ${ }^{16}$

İşkodra valiliği 2 Haziran'da gönderdiği bilgilerde depremin arţ̧ı sarsıntıların devam ettiğini bildirdi. ${ }^{17} 3$ Haziran'da en büyük artçı şoklardan biri yaşandı. Bu artçı şok Ülgün, Tiran, Podgorica ve Tuz'da ağır hasara neden oldu. Haziranın ilk haftası yoğun olarak devam artçı sarsıntılar Temmuz 1906'ya kadar devam etti. Bir yılda 600'ün üzerinde artçı şok kaydedilmiştir. ${ }^{18}$

\section{Depremin Meydana Getirdiği Hasar}

1 Haziran 1905 sabahı meydana gelen İşkodra'da ve çevresindeki köylerde ağır hasara neden oldu. İşkodra Valisi Haydar Paşa, 1 Haziran günü deprem ile ilgili gönderdiği ilk bilgilerde; depremde birçok hanenin yıkıldığını, geri kalanının ise ağır hasar gördüğünü, Müslüman ve Hıristiyan halkın sokaklara döküldüğünü, enkaz altında çok sayıda insan olduğunu, bu sebeple can kaybının çok olabileceğini, mahallelere devriyeler çıkarılarak aramakurtarma çalışmalarının hemen başladığını, askerlerde herhangi bir can kaybının olmadığını ancak askeri binaların ağır hasar gördüğünü, bazı köylerdeki hanelerin tamamının yıkıldığını ve ciddi hasar meydana geldiğini belirtmekteydi. ${ }^{19}$ Belirtilmesi gereken konu bu bilgilerin olayın meydana getirdiği telaş ve endişe ile çok sağlıklı bilgiler olmadığıdır. İlk gelen bilgiler depremin şiddetiyle birlikte tahminlere dayanmaktayd $1 .{ }^{20}$

İşkodra Valisi Haydar Paşa 2 Haziran'da gönderdiği telgrafta afetin büyüklüğünü gözler önüne sermekteydi; "İşkodra ve civar köylerde hiçbir yapı kalmamıştır ki yeniden inşaya ve tamire muhtaç olmasın". Tespit edilen 300'e yakın yaralının tedavisi uygun bir bölgede inşa edilen barakada yapılmaya başlandığı bildirilmiştir. 2 Haziran gecesi yağan şiddetli yağmur depremzedelerin hayat koşullarını bir kat daha zorlaştırmıştır. Yağışlar haziran ayı boyunca devam etmiştir. ${ }^{21}$

İşkodra'dan gelen ilk bilgilerin ardından Osmanlı hükümeti, ilgili kurumları harekete geçirmiştir. Osmanlı hükümeti ağır hasar gören ve kullanılmayacak durumda olan yapıların yıkılmasını, köylerde yaşayanların açıkta bırakılmaması talimatını vermiştir. ${ }^{22}$ Osmanlı belgelerinde İşkodra' da meydana gelen hasar ve yıkım ile ilgili bilgiler kısıtlıdır. Bunun yanı sıra can kaybı ile ilgili bilgiler yok denecek azdır. Dönemin kaynakları, vilayet merkezinde 1500 yapının tamamen yıkıldığını, diğer tüm binaların ağır hasar gördüğünü, şehrin harabeye döndüğünü, 200-250 kişinin hayatını kaybettiğini ve 500-600 kişinin de yaralandığını

\footnotetext{
${ }^{15}$ BOA, BEO. 258/194076, 19 Mayis 1321 (1 Haziran 1905).

${ }^{16}$ Koçiaj- Sulstarova ve diğerleri, age, s. 7-8.

${ }^{17}$ BOA, DH. MKT. 964/14 19 Mayis 1321 (1 Haziran 1905).

${ }^{18}$ Koçiaj- Sulstarova ve diğerleri, age, s. 8; Aurelien van Welden, Christian Beck ve diğerleri, "The Last 500 year of Sedimentation in Shkodra Lake: Paleoenvironmental Evolution and Potential for Paleoseismicity Studies", $J$. Paleolimnal, 40, Springer Science+ Business Media B.V, 2008, s. 620; Sabah, No: 5621, 26 Mayıs 1321 (8 Haziran 1905), s. 3; A. Belar, "1905-1906 Das Erdbeben von Skutari, Erdbebenwarte", 1906, s. 5.

${ }^{19}$ BOA, BEO. 258/194076, 19 Mayıs 1321 (1 Haziran 1905); BOA, DH. MKT. 964/14 19 Mayıs 1321 (1 Haziran 1905); Sabah, Tercüman-1 Hakikat gibi Osmanlı gazeteleri İşkodra depremiyle ilgili ayrıntılı bilgiler yoktur. Sabah, No: 5621, 26 Mayis 1321 (8 Haziran 1905), s. 3.

${ }^{20}$ BOA, DH. MKT. 964/14, 20 Mayis 1321 (2 Haziran 1905).

${ }^{21}$ BOA, BEO. 2589/194172, 20 Mayis 1321 (2 Haziran 1905).

${ }^{22}$ BOA, DH. MKT. 964/14 19 May1s 1321 (1 Haziran 1905).
} 
belirtilmektedir. Şehirdeki evlerin $1 / 5$ 'i yıkıldığı tahmin edilmektedir. ${ }^{23}$ Osmanlı yetkilileri depremin yol açtı ğı maddi hasar ve zararı yaklaşık 12 milyon kuruş olarak tahmin etmekteydi. ${ }^{24}$ Yabancı gözlemcilerin değerlendirmelerine göre zarar yaklaşık 20 milyon Avusturya kronu civarındaydı. ${ }^{25}$ Şehrin güneybatı kısmı depremden çok ciddi bir şekilde etkilendi. Zayıf yapı malzemesi eski binalar depremde yıkıldı veya harabeye döndü. Zayıf duvar ve kiremitlerle kaplı ağır çatılı haneler depremde ağır hasar gördü.

İşkodra'nın kale çevresindeki eski mahalleleri depremden en çok etkilenen bölgelerdi. İşkodra'nın güneydoğu kesiminde yer alan Bahçelik'te tüm evler yıkıldı ve mahalle harabeye döndü. Toprakta meydana gelen çatlaklardan çıkan sular etrafa yayıldı. Drin ve Kir Nehirleri'nin su seviyelerinde yükselmeler oldu ve su taşkınları yaşandı. Buna nehrinde büyük dalgalar meydana geldi. Nehirlerin su seviyelerindeki yükselmeler su baskınlarına neden oldu. Görgü tanıkları, deprem anında suların çok yükseldiğini ifade etmektedir. Berdice mahallesinde de tüm evler yıkıldı. Mahallede 30 kişinin hayatını kaybettiği, 50 kişinin ise yaralandığı belirtilmektedir. Berdice ve Bahçelik mahalleleri arasında büyük çatlaklar meydana geldi ve çatlaklardan beyaz sular çıktığı görüldü. ${ }^{26}$

Dağlardan düşen kaya ve taşlar kale çevresindeki mahallelerde büyük zarara neden oldu. İşkodra Kalesi'nin surları yıkıldı ve taşları aşağı düştü. Bu taşlar Alaybey ve Tabak (Tabake) gibi kalenin aşağısında bulunan mahallelere büyük zarar verdi. Tabak mahallesindeki evlerin tamamı yıkıldı. Mahallede bulunan Kurşunlu Cami hasar gördü. Alaybey'de yapıların hemen hemen tamamı yıkıldı.1905 depreminde en çok can kayıpları İşkodra Kalesi'nin çevresinde bulunan bu mahallelerde yaşand1. Bunun sebebi eski yapılar, kaleden ve dağlardan düşen taş ve kayalard1. ${ }^{27}$

Ajasma mahallesinde bulunan 150 yapıdan $115^{\prime} \mathrm{i}$ yıkılmıştır. Tepe mahallesinde evler diğer

Volume 12

Issue 4

August

2020 mahallelere göre daha az zarar görmüştür. Pazar mahallesinde sadece birkaç dükkân ve ev yıkıldı. Uzmanlar evlerin eski ve sağlam olmamasına rağmen yıkımın bu kadar az olmasını bölgenin zemin yapısına bağlamaktadır. ${ }^{28}$ Isşkodra tarihi çarşısı zarar gördü. İşkodra' da bulunan birçok su kuyusunda yeraltı rejimi ile ilgili değişiklikler görüldü. Bazen suların kaybolduğu belirtilmiştir. $^{29}$

Merkez üssün etki alanındaki Trush, Buşat (Bushat), Beltoja (Beltoje), Kozmaç (Kosmac), Kuç (Kuc), Barbölüş (Barbullush) depremden en çok etkilenen köylerdi. Trush köyünde tüm evler yıkıldı. Toprakta derin ve uzun çatlaklar oluştu. 15 metre derinliğindeki çatlaklardan çıkan sular etrafa yayıldı. Buşat köyünde evlerin çoğu yıkıldı, ayakta kalanlar ise ağır hasar gördü ve harabeye döndü. Dönemin kaynaklarında 20 hanenin olduğu belirtilen Beltoja (Beltoje) köyünde 4 ev tamamen yıkıldı, geri kalanlar ise hasar gördü. Oblik’te evler ahşap kirişlerle inşa edildiği için evlerin çoğu harabeye döndü. Oblik'te can kayıpları yaşandı. Drin Nehri'nin terasları üzerine inşa edilmiş olan Kozmaç'ta evlerin çoğu yıkıldı. Yine Drin Nehri'nin kıyısında bulunan Kuç’ta hanelerin çoğu yıkıldı. Barbölüş’te yapılar yeraltı sularına

${ }^{23}$ Koçiaj- Sulstarova ve diğerleri, age, s. 7.

${ }^{24}$ BOA, DH. MKT. 964/14, 14 Kanun-i evvel 1321 (27 Aralık 1905).

${ }^{25}$ Koçiaj-Sulstarova, "The Earthquake of June 1, 1905, Shkodra, Albania, Intensity Distribution and Macroseismic Epicentre", s. 320.

${ }^{26}$ Koçiaj-Sulstarova, "The Earthquake of June 1, 1905, Shkodra, Albania, Intensity Distribution and Macroseismic Epicentre", s. 323.

${ }_{27}$ Koçiaj- Sulstarova ve diğerleri, age, s. 7-8; Koçiaj-Sulstarova, "The Earthquake of June 1, 1905, Shkodra, Albania, Intensity Distribution and Macroseismic Epicentre", s. 322-325.

${ }^{28}$ Koçiaj-Sulstarova, "The Earthquake of June 1, 1905, Shkodra, Albania, Intensity Distribution and Macroseismic Epicentre", s. 327.

${ }^{29}$ Koçiaj -Sulstarova ve diğerleri, age, s. 7-8. 
sahip gevşek çökeltiler üzerine inşa edildiği için birçok ev yıkıldı ve geri kalanı ise kullanılamaz hale geldi. Toprakta oluşan çatlaklardan kumlu sular çıktı. ${ }^{30}$ İşkodra'nın Berdice ve Bahçelik gibi mahallerinde ve birçok köylerinde heyelanlar yaşandı. Deprem can kaybı ve hasar ile birlikte toprak kayması, göçük, zeminde sıvılaşma, su ve akarsuların akışında değişiklik, nehir kıyılarının çökmesi ve yüzeysel faylanmaları içeren bir dizi jeolojik etkilere de neden oldu.

İşodra valiliği, enkaz kaldırma çalışmalarıyla birlikte hasar tespit çalışmalarına da başlamıştır. Vilayette bulunan bir mühendisin hasar tespit çalışmalarını tek başına yapmasının mümkün olmadığı belirterek iki mühendisin daha gönderilmesini talep edilmiştir. Ticaret ve Nafia Nezareti bunun çok masraflı olacağını belirterek bu ihtiyacın Yanya vilayetinden karşılanması gerektiğini belirtmiştir. Bunun üzerine Yanya Nafia mühendisi bölgeye gönderilmiştir. ${ }^{31}$ Isşkodra'da vali başkanlığında kurulan komisyon hasar tespit çalışmaları ve halkın ihtiyaçlarını tespit için köylere heyetler göndermiştir. ${ }^{32}$ İşkodra depremine ait belgeler şehirdeki hasar tespit çalışmalarına çok az gönderme yapar. Osmanlı belgelerinde vilayet merkezinde ve kırsalında yapılan hasar tespit çalışmalarıyla ilgili ayrıntılı bilgiler yoktur. Bu durum binaların durumu, yapı malzemesi, şehrin yerleşim özellikleriyle ilgili ayrıntılı bilgiler edinmeyi zorlaştırmaktadır. Onarım ve yeniden inşa çalımlarıyla ilgili çok az bilgi vardır. Burada belirtilmesi gereken husus yeniden inşa çalışmasını günümüzün anlayışıyla karıştırmamak gerekir. Osmanlı Devleti deprem sonrası halkın ve özellikle fakir, fukaranın barınma ihtiyaçlarını çadırlarla birlikte barakalar yaprak karşılamaya çalışmıştır. Fakat kentin yeniden inşasında kalıcı konutlar yapımı gibi bir anlayışın o dönemde olmadığını belirtmek gerekir.

Depremde devlet altyapısı ağır hasar görmüş ve kamuya ait birçok bina kullanılamaz hale gelmiştir. Hükümet konağ kullanılamaz hale gelmiştir. Devlet hizmetleri belediye bahçesinde yürütülmeye çalışılmış daha sonra harabeye dönmüş bir askeri koğuştan yürütülmüştür. ${ }^{33}$ Hükümet konağının yeniden inşasına karar verilmiştir. Hükümet konağı yeniden inşa edilene kadar kamu hizmetlerinin yürütülmesi için baraka inşasına karar verilmiştir. ${ }^{34} \mathrm{Bu}$ karardan sonra kışla-i hümayun içerisinde ahşap bir bina yapılmasına başlanmış, bunun için 55.000 kuruşun kış gelmeden inşaatın tamamlanabilmesi için biran evvel gönderilmesi istenmiştir. ${ }^{35}$ Devlet hizmetlerinin aksamaması için her nezaretin kendisine bağlı kurumların masraflarını karşılaması kararlaştırılmıştır Dâhiliye Nezareti hissesine düşen 23.000 kuruş havalenameyi göndermiştir. ${ }^{36}$ Bununla birlikte yeni hükümet konağı inşaatı parasızlıktan durdurulmuştur. Yeni hükümet konă̆ inşa çalışmalarının finansman sıkıntısı sebebiyle gecikmesi üzerine maliyetin gerekirse ianeden karşılanması talep edilmiştir. ${ }^{37}$

İşkodra adliyesi kullanılamaz hale gelmiştir. Adliye memurları önce belediye bahçesinde daha sonra harabeye dönmüş bir askeri koğuşta çalışmak zorunda kalmıştır. Adli hizmetleri yürüten memurlar kötü ve harabeye dönmüş koğuşlarda mahkemelerin görülmesinin devletin imajına zarar verdiğini belirterek şartlarının iyileştirilmesini talep etmişlerdir. Adliye

\footnotetext{
${ }^{30}$ Koçiaj-Sulstarova, "The Earthquake of June 1, 1905, Shkodra, Albania, Intensity Distribution and Macroseismic Epicentre", s. 321-323.

${ }^{31}$ BOA, BEO. 2597702, 30 Mayıs 1321 (12 Haziran 1905).

${ }^{32}$ BOA, BEO. 2591/194316, 22 May1s 1321 (4 Haziran 1905).

${ }^{33}$ BOA, DH. 964/14, 1 Eylül 1321 (14 Eylül 1905); BOA, BEO. 2682/201089, 11 Ağustos 1321 (24 Ağustos 1905).

${ }^{34}$ BOA, BEO. 2678/200829, 20 Eylül 1321 (3 Ekim 1905).

${ }^{35}$ BOA, BEO. 2633/197427, 19 Temmuz 1321 (1Ağustos 1905); BOA, BEO. 2614/196017, 20 Haziran 1321 (3 Temmuz 1905).

${ }^{36}$ BEO, BOA. 2615/196101, 21 Haziran 1905 (4 Temmuz 1905).

${ }^{37}$ BOA, DH. MKT. 964/14, 8 Şubat 1321 ( 21 Şubat 1906).
} 
memurları maaşlarını almadıklarını bu sebeple ailelerini ihtiyaçlarını karşılamada zorlandıklarını belirtmişlerdir. Adli hizmetlerin yürütülmesi için baraka inşasına karar verilmiştir. $^{38}$

Ağır hasar gören kamu binalarından biri de hapishanedir. Depremin meydana geldiği gün 16 mahkûm hapishanenin duvarlarında oluşan çatlaklardan firar girişiminde bulunmuş, firarilerin 14'ü askerler tarafından yakalanmıştır. İşkodra valiliği vilayet merkezinde mahkûmların nakledilebileceği hiçbir sağlam yapı olamadığı için tutukluların kale bodrumlarına nakledildiği bildirmiştir. ${ }^{39}$ Mahkûmları muhafaza için uygun yer aranırken, diğer taraftan İşkodra valiliği cinayet hükümlülerinin başka vilayetlere nakledilmesini talep etmiştir. ${ }^{40} \mathrm{Bu}$ talep üzerine kürek cezasına mahkûm olanların yarısının Bodrum diğer yarısının da Rodos hapishanelerine gönderilmesi kararlaştırılmıştır. ${ }^{41}$ İşkodra merkez hapishanesinde yapılan hasar tespit çalışmalarında tamir ve onarım masrafı 25.403 kuruş olarak tespit edilmiştir. Bu meblağın gelecek senenin ilgili bütçe kalemine eklenerek gönderilmesi kararlaştırılmıştır. ${ }^{42}$

Askeri binalar ve altyapı depremde ciddi hasar görmüştür. Tiran ve Draç dışında, şehir merkezi ve çevredeki kışlalar, karakollar, askeri hastaneler ve Tuz cihetindeki hudut kaleleri ağır hasar görmüş ve bir kısmı kullanılamaz hale gelmiştir. Durumu iyi olan askerler çadırlara yerleştirilmiş, yaralılarda top ambarına sevk edilmiştir. Cephanelikler zarar gördüğü için silahlar, cephaneler ve toplar kaleye gönderilmiştir. Cephanelerin özellikle nemli havadan korunması ve zarar görmemesi için uygun yerlere nakledilmesi ve kış gelmeden cephaneliklerin onarım işlemlerinin bitirilmesi talimatı verilmiştir. ${ }^{43}$ Askeri binaların onarım ve yeniden inşası için 5000 lira talep edilmiştir. ${ }^{44}$ Bu meblağın 200.000 kuruşunu Ergiri, 150.000 kuruşunu Berat, 75.000 Kurşunu Preveze sancaklar1, 75.000 kuruşunun da merkeze bağl1 kazalar tarafından karşılanması ve meblağın gelecek senenin bütçesine eklenmesi kararlaştırılmıştır. ${ }^{45}$ Yanya vilayeti belirtilen sancak ve kazalardan bu meblağın toplanarak İşkodra kumandanlığına gönderilmesini organize etmekteydi. İşkodra kumandanlığı ilk etapta 1500 liranın acilen geri kalanının da peyderpey gönderilmesini talep etmiştir. ${ }^{46}$ Osmanlı Devleti Avrupa sınırında yer alan bu kentteki askeri binaların ve altyapının eski halene getirilmesi hassas davrandığı görülmektedir. Bu sebeple İşkodra kumandanlığına askeri binaların onarım ve yeniden inşası konusunda hızlı hareket etmesi talimatı verilmiştir.

Polislerin kullandığı karakol kullanılamaz hale gelmesi sebebiyle baraka inşasına karar verilmiştir. Barakanın inşası için gerekli olan 1600 kurşun Zabtiye Nezareti bütçesinden karşılanması kararlaştırıldı. ${ }^{47}$

Maarife ait eğitim kurumları, değirmenler ve hamam ciddi hasar görmüştür. Rüştiye mektebi dört tarafında oluşan çatlaklardan dolayı kullanılmaz hale geldiği için eğitime kapatılmıştır. Eğitimin aksamaması ve sınavların zamanında yapılabilmesi için öğrencilerin

\footnotetext{
${ }^{38}$ BOA, BEO. 2682/201089, 22 Eylül 1321 (5 Ekim 1905); BOA, BEO. 2711/203294, 12 Teşrin-i sani 1321 (25 Kasim 1905).

${ }^{39}$ BOA, BEO. 2591/194316, 21 Mayıs 1321 (3 Haziran 1905); BOA, DH. MKT. 964/14, 22 Mayıs 1321 (4 Haziran 1905).

${ }^{40}$ BOA, BEO. 2591/194316, 23 Mayis 1321 (5 Haziran 1905).

${ }^{41}$ BOA, DH. MKT. 964/14, 8 Haziran 1321 (21 Haziran 1905).

${ }^{42}$ BOA, BEO. 964/14, 12 Eylül 1321 (25 Eylül 1905).

${ }^{43}$ BOA, BEO. 2598/194848, 30 Mayis 1321 (12 Haziran 1905); BOA, BEO. 2610/195723, 30 Mayıs 1321 (12 Haziran 1905).

${ }^{44}$ BOA, BEO. 2600/194970, 4 Haziran 1321 (17 Haziran 1905).

${ }^{45}$ BOA, BEO. 2620/194489, 28 Haziran 1905 (11 Temmuz 1905).

${ }^{46}$ BOA, BEO. 2643/198197, 22 Haziran 1321 (5 Temmuz 1905); BOA, BEO. 2610/195723, 16 Haziran 1321 (29

Haziran 1905); BOA, BEO. 2685/201373, 1 Teşrin-i evvel 1321 (14 Ekim 1905).

${ }^{47}$ BOA, DH. MKT. 964/14, 20 Temmuz 1321 ( 2 Ağustos 1905).
} 
yapılacak barakalara aktarılması talep edilmiştir. ${ }^{48}$ Maarif müdürlüğü Padişah tarafından ihsan edilen paranın bir kısmıyla okulların tamir edilmesini talep etmiştir. Maarif Nezareti, vilayetlerden toplanacak ianeden paranın gönderileceğini belirtmiştir. ${ }^{49}$ Osmanlı belgelerinden eylül ayında hala rüştiye mektebinin hasar tespit çalışmasının henüz yapılmadığ anlaşılmaktadır. İşkodra Maarif Müdürlüğü eğitimin başlaması için hasar tespit çalışmalarının biran evvel yapılmasını talep etmiştir. Bu talep üzerine yapılan hasar tespit çalışmasında rüştiye mektebinin hasar keşif bedeli 4822 kuruş olarak belirlenmiştir. ${ }^{50}$ Dülger ustaları şehirde zarar gören diğer yapıların tamir işleriyle uğraştı̆̆ı için mektebin onarım işlerini yürütecek dülger ustası sıkıntısı yaşanacaktır. ${ }^{51}$

Maarife ait olan değirmenlerden biri tamamen yıkılmış diğer ise kısmen hasar görmüştür. Değirmenlerin hasar keşif bedeli 2954 kuruş olarak tespit edilmiştir. ${ }^{52}$ Değirmenlerin tamirine ait yazışmaların 1906 yılında devam ettiği görülmektedir. ${ }^{53}$ İşkodra merkezde bulunan ve devlete ait olan hamam hasar görmüş ve 10.000 kuruşa tamir edilebileceği tespit edilmiştir. Şehirde asker ve halkın gidebileceği başka hamam olmadığı için biran evvel tamir edilmesi talep edilmiştir. ${ }^{54}$

Dini yapılar depremde ağır hasar gördü. Hasar tespit çalışmalarında cami ve mescitlerin keşif bedelleri 40.000 kuruş olarak tespit edilmiştir. Cami ve mescitlerin tamir masraflarının toplanan yardım paralarından karşılanması kararlaştırıldı. Osmanlı arşiv belgelerinde iane paralarının cami ve mescitlerin tamirine yetmemesi nedeniyle harap halde bırakıldığ belirtilmektedir. ${ }^{55}$ Vakıf geliri olmayan dini yapıların depremlerden sonra tamirinin uzun sürdügü görülmektedir. Zarar gören kiliseler ibadete kapatılmıştır. Kilise ve manastır gibi yapıların yeniden inşa çalışmalarıyla yeterli belge yoktur.

Hasar gören binaların tamiri ve yıkılan binaların yeniden inşasının hangi bütçe kaleminden karşılanacağı önemli bir konudur. ${ }^{56}$ Depreme ait belgelerin çoğu mali sorunlara ait belgelerdir. Bütçede tanımlanmış mali kalemler olmadığı için imar ve onarım konusunda sıkıntılar yaşanmıştır. Yapıların onarımı veya yeniden inşası konusunda yaşanan maddi sıkıntıların 1906, 1907 yıllarında da devam ettiği yazışmalardan anlaşılmaktadır. Onarım ve hasarlardan bahseden belgeler; devlete ait yapıların onarım ya da inşasının tam maliyetini değerlendirmek, bölgeye gönderilen memurların harcırahlarının ödenmesi, bütçe bulmak, ne kadar para tahsis edilebileceğini belirlemek, harcamaların hangi bütçe kalemlerine ekleneceği gibi yazışmaları içermektedir. İşkodra depreminde harcamaların karşılanması noktasında Yanya vilayetine önemli talimatlar verildiği görülmektedir. Onarım ve yeniden inşa çalışmalarında gerekli olduğu yerlerde eksikliklerin iane bütçesinden karşılanması kararlaştırılmıştır.

\section{Afet Yönetimi}

Depremlerin olumsuz neticelerinin en asgari seviyede tutulabilmesinin yolu başarılı bir afet yönetimine bağlıydı. Büyük depremler sonrası yaşanan kaos ortamlarında arma kurtarma

\footnotetext{
${ }^{48}$ BOA, MF. MKT. 869/69, 20 Mayıs 1321 (2 Haziran 1905); BOA, MF. MKT. 869/69, 2 Temmuz 1321 (15 Temmuz 1905).

${ }^{49}$ BOA, MF. MKT. 883/3, 7 Haziran 1321 (20 Haziran 1905).

${ }^{50}$ BOA, MF. MKT. 900/54, 5 Eylül 1321 (18 Eylül 1905).

${ }^{51}$ BOA, MF. MKT. 869/24, 5 Teşrin-i evvel 1321 (18 Ekim 1905).

${ }^{52}$ BOA, MF. MKT. 869/24, 28 Teşrin-i sani 1905 (11 Aralık 1905); BOA, MF. MKT. 905/32, 9 Teşrin-i evvel 1321 (12 Ekim 1905).

${ }^{53}$ BOA, MF. MKT. 940/67, 29 Haziran 1906 (12 Temmuz 1906).

${ }^{54}$ BOA, MF. MKT. 891/25, 11 Ağustos 1321 (24 Ağustos 1905).

${ }_{55}$ BOA, BEO. 2828/212046, 30 Nisan 1322 (13 Mayis 1906); BOA, BEO. 2853/213940, 6 Nisan 1322 (19 Nisan 1906).

${ }^{56}$ Selahattin Satılmış, Osmanlı Devleti’nde Afet Yönetimi, İdeal Kültür Yayıncılık, İstanbul 2019, s. 197.
} 
faaliyetleri, evleri yıkılanların iaşe ve barınma ihtiyaçlarının karşılanması, yaralıların tedavi edilmesi ve devlet hizmetlerinin sürdürülebilmesi gereken öncelikli işlerdendi. Bununla birlikte yardımların depremzedelere ulaştırılması, çadır tedariki, dülgerlerin tedariki ve baraka inşa edilmesi, ülke genelinde iane kampanyalarının düzenlenmesi hılı ve etkili devlet organizasyonunu gerektirmekteydi. ${ }^{57}$ Devletin depremzedelerin yanında olduğunu hissettirilmesi, onların korku ve heyecanlarının giderilmesi için İşkodra valiliği harekete geçmiştir. Deprem haberinin İstanbul'a ulaşmasının ardından Hükümet bütün kurumları harekete geçirmiştir. Devlet kurumları verilen talimatla kendi sorumluluk alanlarıyla ilgili çalışmalara başlamışlardır. Merkeze uzak bölgelerdeki afet yönetimi çevre vilayetler aracılığıyla organize edilmeye çalışılmıştır. Afet yönetiminde Yanya ve Selanik vilayetlerinden gönderilen yardımlar önemli bir yere sahip olmuştur.

Hükümetin talimatıyla İşkodra Valisi Haydar Paşa başkanlığında şehrin ileri gelenlerinden oluşan bir komisyon kuruldu. Bütün yönetici kademeleri ve şehrin ileri gelenleri afet yönetiminin içinde yer almaktaydı. İşkodra'da afet yönetimi komisyon tarafindan organize edilmekteydi. Komisyon, halkın barınma ihtiyaçlarının karşılanması için çadır temini ve iaşesini sağlamak için harekete geçmiştir. ${ }^{58}$ Hasar ve halkın zararının tespiti, yeniden inşa çalışmaları için masrafların belirlenmesi, gönderilen yardımların organize edilmesi ve halka ulaştırılması komisyonun en önemli işlerindendi. İşkodra'da valisi bir taraftan komisyon aracılığıyla afet yönetimini sağlamaya çalışırken bir taraftan da İstanbul'a düzenli bilgi veriyordu. Haydar Paşa hasarın çok büyük olduğunu, askeri birliklerde çadır olmaması sebebiyle ilk etapta depremzedelerin barınma ihtiyaçlarının karşılanması için acilen 1000 adet çadır, yaralıların tedavisi için acilen doktor ve iki bin liranın gönderilmesini ve vilayetlerden iane toplanmasını talep etmiştir. ${ }^{59}$ İşkodra valiliğinin talebi üzerine Padişah önce 2000 bin lira bağışlamıştır. Bununla birlikte talep edilen çadırların bölgeye yetiştirilmesi için askeri makamlara talimat verilmiştir. ${ }^{60}$ İşkodra valiliği daha sonra önemli harcamalar için 3000 bin lira daha talep etmiştir. ${ }^{61}$

II. Abdülhamid afetzedeler için 3000 lira daha bağışlamıştır. Padişah tarafından bağışlanan parayı depremzedelere dağıtmak için özel bir heyet-i mahsusa oluşturulmuştur. Heyet-i mahsusa paranın 500 lirasını bölgeye ulaştırarak kişi başına 22 kuruş düşecek şekilde fakirfukaraya dağıtılmasını sağlamıştır. Yardımlar Padişah adına depremzedelere dağıtılmaktaydı. "Felaketzedelerin yegâne koruyucusu olduğu söylemi" Padişah ile halk arasında aracisız kurulmaya çalışan bir diyalog çabasıydı. ${ }^{62}$ Bunun yanı sıra Osmanlı hükümeti de depremzedelerin acil ihtiyaçlarının karşılanması için 1000 lira göndermiştir. İşkodra valiliğinin talep ettiği 1000 çadırın 400’ü 2 Haziran'da Yüzbaşı Veli Efendi'nin refakatinde Nemçe vapuruyla bölgeye gönderilmiştir. ${ }^{63}$ Geri kalanının ise imal edilerek gönderileceği belirtilmiştir. Geri kalan çadırların ve gönderilenlerin yerine yenilerinin yapılması için Adana vilayetine

\footnotetext{
${ }^{57}$ Satılmış, age, s. 44

${ }^{58}$ Sabah, No: 5636, 31 Mayıs 1321 (13 Haziran 1905), s. 2; BOA, BEO. 2591/194316, 22 Mayıs 1321 (4 Haziran 1905).

${ }^{59}$ BOA, BEO. 2607/195501, 11 Haziran 1321 (24 Haziran 1905); BOA, DH. MKT. 964/14, 26 May1s 1321(8 Haziran 1905).

${ }^{60}$ BOA, DH. MKT. 964/14, 20 Mayıs 1321 (2 Haziran 1905); BOA. BEO. 2594/194478, 21 Mayıs 1321 (3 Haziran 1905); Sabah, No: 5621, 26 Mayıs 1321 (8 Haziran 1905), s. 3.

${ }^{61}$ BOA, BEO. 2591/194316, 23 May1s 1321(5 Haziran 1905).

${ }^{62}$ BOA, ML. EEM. 512/43, 16 Haziran 1321 (29 Haziran 1905); BOA, DH. SSF. 358/76, 14 Kanun-i evvel 1321 (27 Ekim 1905); Nadir Özbek, Osmanlı İmparatorluğu’nda Sosyal Devlet, İletişim Yayınları, İstanbul 2016, s. 31.

${ }^{63}$ BOA, Y. PRK. KOM. 14/49, 26 Mayis 1321 (8 Haziran 1905); BOA, BEO. 2589/194172, 20 Mayis 1321 (2 Haziran 1905); BOA, DH. MKT. 964/14, 20 Mayıs 1321 (2 Haziran 1905); Tercüman-ı Hakikat, No: 8672, 23 May1s 1321 (5 Haziran 1905), s. 2.
} 
20.000 bin çadır siparişi verilmiştir. Çadır sıkıntısından dolayısıyla İşkodra valiliğine baraka inşa edilmesi için talimat verilmiştir.

Afet yönetiminin en önemli konu başlıkları barınma ihtiyaçlarının karşılanması konusuydu. On binlerce afetzedeyi barındırmak için biranda çadır bulmak mümkün değildi. ${ }^{64}$ Çadırların gecikebileceği belirtilerek halkın barınma ihtiyaçlarının acilen karşılanması için baraka inşasına başlanması talimatı verildi. ${ }^{65}$ İşkodra valiliği, yaptığı fizibilite çalışmalarından sonra her hanenin nüfusuna göre baraka inşa edilmesine ve baraka masraflarının gönderilecek iane paralarından karşılanmasını kararlaştırdı. ${ }^{66}$ Evleri yıkılan ve hasar görenler arasında fakir ve yardıma muhtaç olanların öncelikli olarak barınma ihtiyaçlarının karşılanmasını istemiştir. Kış gelmeden onarım ve inşa çalışmalarının bitirilmesi amaçlanmaktaydı. Depremzedelerin basit baraklarda kış mevsiminde barınması mümkün olmadığından ahşap, iki kısım halinde inşa edilmesi, bunlar için 116. 600 kuruşun gerektiği yapılan keşif çalışmalarıyla tespit edildi ve hemen gönderilmesi talep edildi. ${ }^{67}$

Afet yönetiminde felaketzedelere sağlık hizmetlerinin ulaştırılması en önemli konulardan biriydi. İşkodra valiliği, yaralıları ve hastaların tedavisi için doktor ve tıbbi malzeme talep etmiştir. ${ }^{68}$ Selanik vilayetinden askeri ve sivil doktorlarla birlikte tıbbi malzeme gönderilmiştir. Şehir merkezinde askerlerden yaralı olanlar yeni inşa edilmiş olan top ambarına nakledilerek tedavilerine başlanmıştır. Halk için büyük bir baraka inşa edilerek yaralıların tedavisine burada devam edilmiştir. Köylere sağlık heyetleri gönderilerek yaralıların tedavileri sağlanmış ve ilaç yardımında bulunulmuştur. ${ }^{69}$

Osmanlı hükümeti depremzedelere kişi başına 23 kuruş maddi yardım yapmayı kararlaştırdı. Örneğin, 4 kişilik bir haneye 92 kuruş, 6 kişilik hane 138 kuruş, 10 kişilik bir haneye 230 kuruş yardım yapılmaktaydı. İlk etapta 11.519 kişiye 264.937 kuruş yardım yapılmıştır. Bu yardımlar mahallelerde kurulan komisyonlar aracıllığıyla ihtiyaç sahiplerine ulaştırılmaktayd.$^{70}$

Depremin meydana geldiği günlerde Osmanlı ülkesinde nüfus sayımı yapılmaktaydı. Deprem nedeniyle nüfus sayımlarının diğer vilayetlerde yapıldıktan sonra İşkodra' da yapılması kararlaştırılmıştır. ${ }^{71}$ Hristiyanların bedelat-1 askeriye vergileri ertelendi. ${ }^{72}$

Osmanlı hükümeti ve İşkodra valiliği depremin yaralarını sarmaya çalışırken Ekim 1905 'te 15 gün boyunca devam eden şiddetli yağışlar sele neden olmuştur. İşkodra'ya dört beş saat mesafede bulunan bölgeler su altında kalmıştır. Sel felaketi depremzedelerin zor olan hayat şartlarını bir kat daha zorlaştırmıştır. Özellikle köylerde yaşam şartları daha da zorlaştığ insanların kayıklarla hanelerinden çıkmak zorunda kaldığı bildirilmiştir. ${ }^{73}$ İşkodra belediyesi selden etkilenen bölgelere ekmek ve insani yardım sevk etmiştir. Selden etkilenenler için

${ }^{64}$ Satılmış, age, s. 82; BOA, BEO. 2611/195769, 14 Eylül 1321 (27 Eylül 1905).

${ }^{65}$ BOA, BEO. 2614/196028, 19 Haziran 1321 (2 Temmuz 1905).

${ }^{66}$ BOA, DH. MKT. 964/14, 11 Haziran 1321 (24 Haziran 1905).

${ }^{67}$ BOA, DH. MKT. 964/14, 10 Eylül 1321 (23 Eylül 1905).

${ }^{68}$ BOA, DH. MKT. 964/14, 26 May1s 1321 (8 Haziran 1905).

${ }^{69}$ BOA, Y. PRK. UM. 76/61, 28 Haziran 1321 (10 Temmuz 1905); BOA, DH. MKT. 964/14, 26 May1s 1321 (8 Haziran 1905); BOA, $\dot{I}$. DH. 1446/25, 13 May1s 1322 (26 May1s 1906).

${ }^{70}$ BOA, Y. PRK. UM. 76/61, 10 Haziran 1321 (23 Haziran 1905).

${ }^{71} B O A, M V .111$.

${ }^{72}$ BOA, BEO. 2696/202016, 13 Teşrin-i evvel 1321 (26 Ekim 1905); BOA. MV. 119/6.

${ }^{73}$ BOA, BEO. 2694/202016, 19 Teşrin-i evvel 1321 (1 Kasım 1905). 


\section{Özer Özbozdağlı}

yardım talep edilmiştir. Osmanlı hükümeti sel felaketini sebebiyle depremzedeler için toplanan ianeden bölgeye 113.00 kuruş göndermiştir. ${ }^{74}$

\subsection{Yardım Kampanyaları}

Afet yönetimi her şeyden önce ciddi bir finansman gerektirmekteydi. Depremden etkilenen on binlerce kişinin barınma, iaşe ve sağlık ihtiyaçlarının karşılanması Osmanlı bütçe ve maliyesi için çok büyük bir rakamdı ${ }^{75}$ Beklenmedik harcamalar devlet hazinesine ek bir yük getirmekteydi. Bu tür harcamalar için Osmanlı bütçesinden ayrılmış kaynaklar yoktu. Devletin bütçesi böyle bir yükü kaldıracak durumda değildi. Bu sebeple Sultan II. Abdülhamid, döneminde finansman için politika değişikliğine gidildi. Bu dönemde ülke çapında düzenlenen yardım kampanyalarıyla toplanan yardımlarla depremin yaraları sarılmaya çalışılmıştır. Bu sayede iflas etmiş durumda olan devlet hazinesine artı yükler binmesinin önüne geçilmeye çalışılmaktayd.. ${ }^{76}$

İşkodra depreminden sonra depremzedelerin ihtiyaçlarını karşılamak için İstanbul'da bir iane komisyon kurulması kararlaştırıldı. Bu komisyon İstanbul'dan ve hükümet erkânından toplanacak ianeleri organize edecekti. II. Abdülhamid deprem bölgesine gönderilecek yardımları organize etmesi için Şehremanetini görevlendirmekteydi. ${ }^{77}$ Şehremaneti'nde kurulmuş olan iane komisyonu yardımları organize etmekteydi. Yardımlar padişah adına toplanmaktayd1. Sultan ilk önce kendisi bağışta bulunmaktayd $1{ }^{78}$ Gazetelerde depremzedeler için Padişah adına iane toplanacağı dair ilanlar verildi. İlanlarda şöyle deniyordu: "İşkodra' $d a$ zuhura gelen tezelzülat-ı arziyede musab olan kardaşlarımıza dahi Osmanlılara ve Osmanlılı̆̆a yaraşırcasına muavene-i hamiyetmendiye şetiban olacaklarına hiç kimse şüphe etmeyecektir."

Volume 12

Issue 4

August

2020

İane kampanyasının düzenli ve kontrollü yapılması için vilayetlerde de iane komisyonları kurulması ve toplanan paraların bu komisyonlar aracılığıyla Şehremanetine gönderilmesi kararlaştırıldı. Bu kapsamda iane biletlerinin basılarak vilayetlere gönderilmesi talimat verildi. İane biletlerinin basım işini ücretsiz olarak Sabah gazetesi imtiyaz sahibi üstlenmiştir. Vilayetlerin ne kadar iane toplayabileceklerini bildirimleri istendi. ${ }^{80}$ Valiliklerin toplayabilecekleri iane miktarlarını bildirmesinden sonra halkın ekonomik durumuna göre biletler bastırılarak gönderilmiştir. Örneğin, Yanya vilayeti iane komisyonu vilayette 100 kuruşluk yardım yapabilecek çok nadir kişi olduğunu belirterek, 100 kuruşluk biletleri iade etmiştir. ${ }^{81}$ Vilayetler halktan toplanan yardımları Osmanlı Bankası veya posta aracılığıyla

\footnotetext{
${ }^{74}$ BOA, BEO. 2694/202016, 19 Teşrin-i evvel 1321 (1 Kasım 1905); BOA, BEO. 2699/202412, 20 Teşrin-i evvel 1321 ( 2 Kasim 1905).

${ }^{75}$ Yasemin Avcı, “Osmanlı Devleti’nde Afet Yönetimi ve 1899 Denizli Depremi”, Uluslararası Denizli ve Çevresi Tarih ve Kültür Sempozyumu, Isparta 2007, s. 36.

${ }^{76}$ Satılmıs, age, s. 51.

${ }^{77}$ Şehremanetini büyük afetler sonrası iane için görevlendirme geleneği 1894 İstanbul depremiyle başlamıştır. 1894 depreminde zarar gören ve yardıma muhtaç halkın çadır, yiyecek vs. hususlarda ihtiyaçlarının karşılanması, iane toplanması, yaralıların belediye hastanelerine nakliye tedavilerinin sağlanması gibi vazifelerin düzenli bir şekilde yerine getirilmek üzere Padişah'ın emriyle İstanbul'da Şehremaneti bünyesi İane-i Musabin Komisyonu kurulmuştur. Bu komisyon büyük depremler ve afetlerden sonra işlerlik kazandırılmıştır. Daha geniş bilgi için bkz. Fatma Ürekli, Ístanbul'da 1894 Depremi, İletişim Yayınları, İstanbul 1999, s. 75.

${ }^{78}$ BOA, DH. MKT. 964/14, 20 Mayis 1321 (2 Haziran 1905); BOA, BEO. 2591/194317, 23 May1s 1321 (5 Haziran 1905); BOA, I. HUS. 130/6, 25 May1s 1321 (7 Haziran 1905).

${ }^{79}$ Sabah, No: 5621, 26 Mayis 1321 (8 Haziran 1905), s. 2.

${ }^{80}$ BOA, DH. MKT. 964/14, 1 Haziran 1321 (14 Haziran 1905); Sabah, No:5624, 29 Mayıs 1321 (24 Haziran 1905), s. 3.

${ }^{81}$ BOA, DH. MKT. 964/14, 21 Ağustos 1321 (3 Eylül 1905); BOA, BEO. 2607/195501, 11 Haziran 1321 (24 Haziran 1905); BOA, DH. MKT. 964/14, 11 Teşrin-i evvel 1321 (24 Ekim 1905).
} 
Şehremanetine ulaştırmaktaydı. Paraların alındığına dair düzenlenen makbuzlar Dâhiliye Nezareti tarafından vilayetlere ulaştırılmaktaydı ${ }^{82}$

İane biletleri talep eden vilayetlerin topladığ iane; Bağdat 20.000, Kosova 30.000, Hüdavendigar 50.000, Halep 20.000, Mamuretülaziz 15.000, Selanik 50.000, Cezayir-i Bahr-i Sefis 3655, Edirne 8356, Cebel-i Lübnan 25.917, Yanya 11.206, Adana 9381, Kudüs-ü Şerif 82.049 kuruştu. Bilet talep etmeyen vilayetlerin topladığ 1 yardımlar; Konya 20.000, Trabzon 14.374, Ankara 7200, Kastamonu 6505, Musul 4073, Beyrut 10.000, Bolu 375 kuruştu. Vilayetlerden toplam 388. 091 kuruş iane toplanmıştır. Bunun yanı sıra İşkodra'ya bağlı sancaklardan toplanan iane doğrudan valiliğe gönderilmiştir. ${ }^{83}$

Şehremaneti, iane komisyonunda toplanan parayı depremzedelerin ihtiyaçlarını karşılanması ve onarım faaliyetleri için peyderpey bölgeye ulaştırmaktaydı. Osmanlı hükümeti iane parasından 296.000 kuruşu bölgeye göndermiştir. ${ }^{84}$ Bununla birlikte İstanbul'da toplanan 52.279 kuruş afet bölgesine gönderilmiştir. ${ }^{85}$ Sel felaketzedeleri için ise 113.920 kuruş gönderilmiştir. ${ }^{86}$

Ülke çapında toplanan yardımlar dönemin merkeziyetçilik anlayışına uygun olarak İstanbul'dan organize edilmiştir. Bütün yardımlar padişah adına toplanmakta ve depremzedelere ulaştırılmaktaydı.

\subsection{Uluslararası Yardımlar}

Batılı ülkeler Osmanlı Devleti'nde meydana gelen birçok deprem sonrasında doğrudan veya nakdi yardım girişiminde bulunmaktaydı. ${ }^{87}$ Yardımlar konsolosluklar aracılığıyla Osmanlı Devleti'ne ulaştırılmaktaydı. Bununla birlikte İşkodra'da kurulmuş olan komisyon konsolosluklar nezdinde yardım girişiminde bulunmuştur. ${ }^{88}$ Avusturya İmparatoru depremzedeler için bağışlanan 25.000 Kron İşkodra konsolosu aracığıyla bölgeye ulaştırılmıştır. Avusturya asilzadeleri gazeteler aracılığıyla hem geçmiş olsun mesajları yayınlamışlar hem de topladıkları yardımları İşkodra'ya göndermişlerdir. ${ }^{89}$ İtalya hükümeti de afetzedeler için 25.000 kron bağışlamıştır. İngiltere ilk etapta afetzedeler için bölgeye çadır göndermiştir. ${ }^{90}$ İngiltere'nin Manchester kenti Belediye başkanı bir yardım komisyonu kurmuştur. Komisyon toplamış olduğu 120 bin franklık yardımı Osmanlı Şehbenderine teslim etmiştir. ${ }^{91}$

Karadağ Prensi başsağlığı ve geçmiş olsun mesajını Çetine konsolosu aracılığıyla İstanbul'a iletmiştir. $^{92}$ Bununla birlikte Karadağ hükümeti depremin meydana geldiği gün konsoloslar

\footnotetext{
${ }^{82}$ BOA, DH. MKT. 964/14, 12 Kanun-i evvel 1321 (25 Aralık 1905).

${ }^{83}$ BOA, DH. MKT. 964/14; BOA, BEO. 2738/205336, 30 Kanun-i evvel 1321 (12 Ocak 1321).

84 BOA. BEO. 2694/202016, 19 Teşrin-i evvel 1321 (1 Kasım 1905).

85 BOA, DH. MKT. 964/14, 6 Teşrin-i sani 1321 (19 Kasım 1905); BOA, BEO. 2699/202412, 20 Teşrin-i evvel 1321 ( 2 Kasim 1905).

${ }^{86}$ BOA, DH. MKT. 964/14, 29 Kanun-i evvel 1321 (11 Ocak 1906).

${ }^{87}$ Satılmış, age, s. 164.

${ }^{88}$ BOA, DH. MKT. 964/14, 19 Kanun-i evvel 1321 (1 Ocak 1906).

${ }^{89}$ BOA, Y. PRK. ESA. 47/84, 7 Haziran 1321 (20 Haziran 1905); BOA, DH. MKT. 964/14, 3 Şubat 1321 (16 Şubat 1906).

${ }^{90}$ BOA, DH. MKT. 964/14, 28 May1s 1321 (10 Haziran 1905); BOA, BEO. 2593/194464, 31 May1s 1321(13 Haziran 1905); BOA, BEO. 2753/206458, 17 Kanun-i evvel 1321(30 Aralık 1905).

${ }^{91}$ BOA, DH. MKT. 964/14, 19 Teşrin-i evvel 1321 (1 Kasım 1905); BOA, BEO. 2714/203546, 23 Teşrin-i sani 1321 (6 Aralık 1905).

92 BOA, BEO. 2593/194472, 26 Mayıs 1321 (8 Temmuz 1905); BOA, Y.A.HUS. 488/9, 23 Mayıs 1321 (5 Haziran 1321).
} 
Özer Özbozdağlı

için bölgeye çadır göndermiştir. ${ }^{93}$ Avusturya'da Venedik Anveyn adlı dinlenme tesisi müdürü Mösyö Gabor Schneiter depremzedeler için toplanan 1200 kronu (5900 kuruş) İstanbul'a göndermiştir. ${ }^{94}$ Depremzedeler için gönderilen bu uluslararası yardımlarla birlikte Osmanlı Devleti İşkodra'nın yaralarını sarmaya çalışmıştır. 1905 depremi İşkodra vilayetinin gelişimini her anlamda olumuz etkilemiş bir olaydır. Depremden sonra İşkodra vilayeti bir daha eski görünümüne kavuşamadı.

\section{Sonuç}

Depremler yaşamın her alanını etkilemesi sebebiyle tarihsel olguların ortaya çıkmasına neden olmaktadır. Depremin insan üzerinde yarattığı can kayıpları, travmalar, göç, yerleşim yerlerinin yeniden şekillenmesi, tarihi yapılar üzerinde yarattığ 1 tahribat gibi konular depremin sonuçları olarak incelenmesi gereken tarihi olgulardır. Bunun yanı sıra geçmiş depremlerin incelenmesi sismologlara geleceğe dönük öngörü için önemli veri sağlamaktadır. Bu bağlamda depremler üzerine yapılacak çalışmalar geleceğe yönelik önemli projeksiyon sağlamaktadır. İşkodra tarihi de incelendiğinde depremlerden ağır hasar gördüğü görülmektedir. Bu depremlerden biri de 1905 depremidir.

1 Haziran 1905 depremi İşkodra'da can kayıplarına ve ağır hasara neden oldu. Kırsal alanı harabeye çeviren depremde 200-250 kişi hayatını kaybetmiş, 600'den fazla insan yaralanmıştır. Vilayet merkezindeki yapılardan 1500’ü yap1 tamamen yıkılırken, depremin merkez üssüne yakın köyler harabeye dönmüştür. Devlet alt yapısı ağır hasar görmüş ve birçok bina kullanılamaz hale gelmiştir. Deprem haberinin İstanbul'a ulaşmasından sonra Osmanlı hükümeti afet yönetimi için harekete geçti. Devletin kurumlan kendilerini ilgilendiren konularda çalışmalar yapmaya başladı. İşkodra valiliğinin talepleri doğrultusunda bölgeye çadır, besin ve sağlık malzemeleri gönderilmeye başlandı. Padişah depremzedeler için özel hazinesinden ihsanda bulunmuş, para özel bir heyet aracıllı̆̆ıla bölgeye götürülmüştür. Halkın barınma ihtiyaçlarının karşılanması için yeterli çadır gönderilemediği için baraka inşa edilmesi karar verilmiştir. Bunun yanı sıra İşkodra'nın merkeze uzak olması nedeniyle bazı yardımlar çevre vilayetlerden organize edilmiştir. Yanya ve Selanik vilayetleri bu yardımlarda önemli iki kent konumundadır. Bütün koordinasyon İstanbul'dan yapılmıştır. Afeti finanse temek etmek için ülke genelinde iane toplamasına karar verildi.

II. Abdülhamit dönemin beklenmedik bu tarihi olayların getirdiği mali yüklerin bütçeye yük olmaması için politika değişikliğine gidilmiş İmparatorluk çapında ianeler toplanmaya başlanmıştır. Bir noktada gelenek icat edilmiş̧i: "İANE". İşkodra depremzedeleri için ülke genelinde iane toplanmış ve bölgeye gönderilmiştir. Bunun yanı sıra uluslararası insani yardımlar konsolosluklar aracılığıla bölgeye ulaştırılmıştır. Osmanlı Devleti ianeler ve uluslararası yardımlarla depremin yaralarını sarmaya çalışmıştır. Bütün bunlarla birlikte Osmanlı Devleti'nin depremle mücadele edecek bir teşkilatının olmaması afet yönetimi konusunda bazı sorunların çözümünü geciktirdiğini belirtmek gerekir.

1905 depremi İşkodra'nın tarihi gelişimini olumsuz etkilenmiştir. İşkodra'nın deprem öncesi durumuna bir daha dönemediğini belirtmek gerekir. Şehrin özellikle kale çevresindeki eski mahalleleri bir daha eski görünümüne kavuşamadı.

\footnotetext{
${ }^{93}$ BOA, I. HUS. 48/89, 25 Mayıs 1321 (7 Haziran 1905); Tercüman-ı Hakikat, No: 8674, 25 Mayıs 1321 ( 7 Haziran 1905), s. 3.

${ }^{94}$ BOA, HR. TH. 322/3, 19 Temmuz 1321, (1 Ağustos 1905).
} 


\section{Kaynakça}

\section{Arşiv Belgeleri}

\section{Cumhurbaşkanlığı Devlet Arşivleri Başkanlığı Osmanlı Arşivi (BOA)}

Babıâli Evrak Odas1 (BEO):2643/198197; 2633/197427; 2620/196498; 2615/196101; 2600/194970; 2598/194848; 2597/194702; 2594/194478; 2593/194464; 2591/194314; $2591 / 194316 ; 2589 / 194172 ; 2711 / 194172 ; 2711 / 203294 ; 2714 / 203546 ; 2591 / 194316$; 2614/196017; 2593/194472; 2614/196028; 2611/195769; 2610/195723; 2853/213940; 2753/206458; 2699/202412; 2694/202016; 258/194076; 2696/202016; 2682/201089.

Dâhiliye Nezareti Mektubi Kalemi (DH. MKT.): 964/14.

Dâhiliye Nezareti Şifre Kalemi (DH. ŞFR. ): 358/76.

Hariciye Nezareti Tahrirat Kalemi (HR. TH.): 322/3.

İrade Hususi (İ. HUS.): 136/6.

Maarif Nezareti Mektubi Kalemi (MF. MKT.): 900/54;896/24;891/25; 869/69;905/32; 883/3.

Yıldız Hususi Maruzat Kalemi (Y.A.HUS.): 48/89.

Yıldız Perakende Evrakı Elçilik, Şehbenderlik ve Ateşemiliterlik ( Y. PRK. EŞA.): 47/84.

Yıldız Perakende Evrakı Komisyonlar Maruzatı (Y. PRK. KOM.): 14/49.

Y1ldı Perakende Evrak-1 Umumi (Y. PRK. UM.): 76/61.

\section{Süreli Yayınlar}

Sabah

Tercüman-1 Hakikat

Salname-i Devlet-i Aliyye-i Osmaniyye, 1323 (1905) Sene-i Hicriyesine Mahsus, Matbaa-i Ahmed İhsan, Dersaadet 1321.

\section{Kitaplar ve Makaleler}

AMBRASEYS, Nicolas, Earthquakes in the Mediterranean and Middle East: A Multidisciplinary Study of Seismicity up to 1900, London: Cambridege University Press, London 2009.

AVCI, Yasemin, “Osmanlı Devleti'nde Afet Yönetimi ve 1899 Denizli Depremi”, Uluslararası Denizli ve Çevresi Tarih ve Kültür Sempozyumu, Fakülte Kitabevi, Isparta 2007, s. 361367.

BELAR, A, "DAS Erdbeben von Skutari, Erdbebenwarte", 1906, s. 5-8.

CLAYER, Nathalie, Arnavut Milliyetçiliğinin Kökenleri, Çev. Ali Berktay, İstanbul Bilgi Üniversitesi Yayınları. İstanbul, 2013.

ERKEN, İlkay, İskodra Vilayetinin İdari ve Sosyal Yapısı 1876-1912, Ondokuz Mayı Üniversitesi Sosyal Bilimler Enstitüsü, Yayınlanmamış Yüksek Lisans Tezi, Samsun 2014.

KİEL, Machiel, “İşkodra”, Türk Diyanet Vakfi İslam Ansiklopedisi, C. 23, Diyanet Vakfı Yayınlar1, İstanbul 2001, s. 433-434.

ÖZBEK, Nadir, Osmanlı Imparatorluğu’nda Sosyal Devlet, İletişim Yayınları, İstanbul 2016. 
ÖZBOZDAĞLI, Özer, “Osmanlı Makedonya'sında 4 Nisan 1904 Depremi ve Sonuçları”, Ankara Üniversitesi Tarih Araştırmaları Dergisi, Ankara 2020, s. 435-476.

KOÇİAJ, Siasi - SULSTAROVA, E. (1980), "The Earthquake of June 1, 1905, Shkodra, Albania, Intensity Distribution and Macroseismic Epicentre", Tectonophysics, C.67, S. 34, 1980, pp. 319-332.

KOÇİAJ, Siasi, "Recent seismic activity in Albania and its Features", Mud Volcanoes, Geodynamics and Seismicty, Netherland 2005, pp. 123-133.

Koçiaj, Siasi- SULSTAROVA, E ve diğerleri. (2010), Seismicity, Seismotectonics and Seismic Hazard Assessment in Albania, Academy Of Sciences of Albanina, Tiran 2010.

SATILMIŞ, Selahattin, Osmanlı Devleti'nde Afet Yönetimi, İdeal Kültür Yayıncılık, İstanbul 2019.

ŞAHİN, Cemalettin- Si̇PAHİĞLU, Şengün, Doğal Afetler ve Türkiye, Gündüz Eğitim ve Yayıncılık, Ankara 2007.

ÜREKLİ, Fatma, İstanbul'da 1894 Depremi, İletişim Yayınları, İstanbul 1999.

VOGT, Jean, "Osmanlı Topraklarında Tarih Boyunca Depremsellik", Osmanlı Imparatorluğu'nda Doğal Afetler, Ed. Elizabeth Zachatadou, Tarih Vakfı Yurt Yayınları, İstanbul 2001, s. 13-58.

WELDEN, Aurelien van- BECK, Christian ve diğerleri, "The Last 500 year of Sedimentation in Shkodra Lake: Paleoenvironmental Evolution and Potential for Paleoseismicity Studies", Journal of Paleolimnal, 40, Springer Science+ Business Media B.V., 2008, pp. 619-633.

https://deprem.sdu.edu.tr/tr/sismolojik-terimler/sismolojik-terimler-636s.html (E.T. 4.4.2020). 